る事によりスキャンタイムを縮少する事が出来，しか6 画像再生上，情報不足を来たす事皇なかった。 RCT は， 特に脳シンチ，肝シシチ， ${ }^{201} \mathrm{Tl}$ による心筋シンチ，副腎 シンチ等に有効であった，その他の臟器について羊検討 中である。今後, 吸収補正の問題等ソフトウェアの一層 の開発が望まれる。

\section{RI 多層断層装置（Pho/Con）の基礎的検討}

\section{愛媛大学医学部附属病院放射線部}

○上田幸介 -中田 茂 : 川上寿炤

$\mathrm{RI}$ 多層断層装置 $(\mathrm{PHO} / \mathrm{CON})$ の画質特性について 内径 $0.25 \mathrm{~mm}$ のポリエチレンチューブを用い, 主とし てFWHM の測定を行い，各断痛面の鮮鋭度，他の面の 線源からの笴与，スキャンスピードによる変化，均一性， 解像力等について検討を加えた。コリメー夕は，低エネ ルギー用高感度，高分解能，及び中エネルギ一用の 3 種 類を使用した。

〔結果】各断層面の特性は一定にしたものが得られな かったが，焦点面に近いほど良い特性を示した，全体的 には，高分解能コリメータが最も安定した特性を示し， 高感度，中エネルギー用はかなりのバラツキを示した。 このバラッキも装置を調整することにより，改善出来る あのと考える.

\section{2. シシチレーションカメラを用いた ECT 装置}

(株)島津慗作所医用技術部

○田中三博・中西重昌・小沢缉史

(株)島津製作所医用技術部システム部 池田 豊

大型視野シンチレーションカメラを用いて, 単一光子

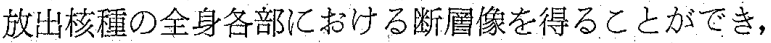
全身スキャンを含むイメ゙ージングす行なうととのできる 装置を開発した。本装置は，検出器スタンド，ベッド， モータコントロール部, データ処理装置加ら成ってい る.

ECTを行なうには，專用の天板をべッドに取り付汁， 検出器を患者の回りに連続回転（2 分〜 60分) またはス テップ回転（最小 $2^{\circ}, 1^{\circ}$ 每に任意設定）させる. 回転半 径は $0 \sim 30 \mathrm{~cm}$ である. 画像再棈成は，デー夕採取と並 行して行なわれ所要時間は約 1 分である. 再棈成方法と

してはフィルタードバックプロシェタション法を用いて いる，吸収補正は患者の体を円又は管円近似しておし なう。

103. 汎用ガンマカメラを用いた RCT の使用経験

国立がんセンター放射線診断部 ○福喜多博義
アイソトープ彭断室 川合英夫

我々は島津 RCT 用ソフトウェアの提供を受け同時に RCT 用回転椅子を作成し，使用する機会を得たのでそ の使用経験について報告する，基礎実験で解像力では， hot lesion で $1.0 \mathrm{~cm} \phi$, cold lesion で $2.4 \mathrm{~cm} \phi の む の$ で検出するとと办出来た。症例数は現在迄に30例を超え， 主に原発性肝癌を疑われた症例てついての肝 RCT を行 なった。結論亡して, 解像力の悪さ吸収補正の難しさ等 まだまだ問題点もあるが，今後との RCT 像を，肝蔵の 区域切除の際の operability の判定に，あるいは tumor の大きさの推定 (volume 計算) に危用してゆく予定で ある。

\section{Single Photon RCT の基礎的検討}

大阪市立大学医学部附属病院中央放射線部

○大村冒弘・浜田国雄 池田穂積 ·越智宏惕

丸文株式会社医用電子機器部 原 政直

われわれは日裳使用しているシンチカメラ（OHIO NUCLEAR $\Sigma 410$ S) とコンピュータ (Informatek Simis 3) に加えて武作回転台を用いて single photon RCT を 試みた。われわれの方法ではコンピュータの制御によっ て患者を 9 度ごと 360 度回転させ，データを収集し，そ のデータより Transaxial 像を得, つづてて Frontal, Sagittal 像の各方向の断層像を得た。 われわれの方法の基 礎的検討では均一性は標準偏差が $6.3 \%$ であり，データ 量を多くすると良くなる傾向《あった。分解能は， FWHM で $2.5 \mathrm{~cm}$ であり, cold lesion 検出能は $1.5 \mathrm{~cm}$ がほぼ識別でき, hot lesion 検出能は $1.5 \mathrm{~cm}$ が識別可 能であった。臨床的検討ですほぼ満足できる結果が得ら れた。

\section{RCT（トモスキャナII）の基礎的検討}

国家公務員共済組合連合会虎の閏病院 中央放射線部

○斎藤京子・大久保明彦

泉 英世・大波一男

RI 横断断層シンチグラフィ専用装置（スキャナ方式） の基礎的検討を行なう。検出器間距離が $50 \mathrm{~cm}$ の場合の 分解能は FWHM で $2.3 \mathrm{~cm}$ であるが，検出器間距離を 広げると鱼化する：國転中心でのスライス擪は $2.4 \mathrm{~cm}$ ， 回転中心から $10 \mathrm{~cm}$ 離れた点で $2 \mathrm{~cm}$ となり，回転中心 部がやや厚い。 ${ }^{99 \mathrm{~m}} \mathrm{Tc}$ の吸收補正プログラム使用により 深部の計数值の低下は補正されるが， radio activityと ROI からの計数值とは必ずしも一致しない. 深部ほどそ 